Anastasia Furdychko, Marta Ilchyshyn, Adriana Barylyak,

Irena Fedun, Lesya Khoroz

\title{
Development features \\ of periodontal tissues inflammatory diseases of nicotine-dependent patients with chronic toxic hepatitis
}

\author{
Danylo Halytsky Lviv National Medical University, Lviv, Ukraine
}

\begin{abstract}
Introduction. Liver diseases and pathology of the organs of mouth cavity are interconnected. Smoking, usually increases the manifestations of the underlying disease and affects the course.

The aim. To investigate the effect of chronic toxic hepatitis of nicotine-dependent patients and of patients without a bad habit on their periodontal status.

Materials and methods. During the clinical examination of the oral cavity of 86 patients, the depth and incidence of inflammation of the gum were determined using the number of the Svrakov's number (SN); the conditions of hygiene of the oral cavity were estimated using the Silness-Loe (S-I) index; Periodontal Index (PMA) and Bleeding Index (PBI). General histomorphology was studied on drugs stained with hematoxilin-eosin and by the method of Gerlich and van Gieson.

Results. It is established that the indicator of SN had the highest value among patients of group II $(2,15 \pm 0,13)$, it was probably $(p<0.05)$ higher relatively to the group I and comparison group. In the smoking patients with chronic toxic hepatitis, in spinous layer of epithelium was determinanted karyorhexis, karyolysis with the formation of cell debris; basal layer cell proliferation, acanthosis, angiogenesis. We detected damage to collagen and elastic fibers of the periodontal, wich correlated with the intensity and duration of the bad habit. In areas of pronounced alterative changes colonies of bacteria were discovered.

Conclusions. Thus, the results obtained in nicotine-dependent patients with chronic toxic hepatitis visualize damaging effect on the epithelium and weakening of the histohematic barrier of the oral cavity and promotes the reproduction and penetrationof pathogenic microflora into the underlying tissues.
\end{abstract}

Keywords: periodontium, chronic toxic hepatitis, nicotine-dependent.

The work is a fragment of a complex research topic of the Department of Therapeutic Dentistry of Danylo Halytskyy Lviv National Medical University "Development and improvement of methods for diagnosis, prevention and treatment of periodontitis, caries and its complications" (registration № 0120U002139).

\section{Introduction}

Liver diseases occupy one of the leading places in the pathology of the human body. The correlation between liver diseases and pathology of the organs of mouth cavity is due to violations of the barrier and antimicrobial function of the liver, resulting in translocation of opportunistic bacteria into organs and tissues of the human body, including the oral cavity [1, 2, 3, 4]. The presence of patients' bad habit, namely smoking, usually increases the manifestations of the underlying disease, the course of which becomes longer and more severe $[5,6,7,8,9,10,11]$.
The aim - to investigate the effect of chronic toxic hepatitis of nicotine-dependent patients and of patients without a bad habit on their periodontal status.

Materials and methods

86 patients were examined. Among them - 22 with inflammatory periodontal disease (IPD) without chronic toxic hepatitis, non-smokers (comparison group); 26 patients with chronic toxic hepatitis, non-smokers (group I) and 38 - Smoking patients with chronic toxic hepatitis (group II). The age of patients was 29-47 years, of which $67.4 \%(58 / 86)$ - women and $32.6 \%$ $(28 / 86)-$ men.

In the course of clinical examination of patients the depth and prevalence of the inflammatory process of the gums were determined with the help of the Svrakov's number (SN); the conditions of oral cavity hygiene were evaluated using the Silness-Loe index (S-1); periodontal index (PMA), and bleeding index (PBI). 
The exclusion criteria were patients with: dentofacial anomalies and deformities, extended defects of the dentition and pathological abrasion, orthodontic devices, patients with chronic viral hepatitis, the presence of focal liver lesions, HIV infection, active tuberculosis, antiviral therapy with interferon, the presence of concomitant diseases of the digestive system, diabetes, tumors of any localization, refusal of the patient from examination.

The condition of patients with chronic toxic hepatitis was assessed by doctors of Gastro-enterological Department of Zolochiv district hospital in Lviv region. Patients with chronic toxic hepatitis received medical treatment in accordance with the treatment Protocol by specialists in this field.

All patients underwent complex treatment of periodontal disease. Individual hygienic regime of the oral cavity was appointed, followed by control over the degree of teeth purification from dental plaque, toothbrush and toothpaste were selected individually. Solid dental deposits were removed by the ultrasound machine "Piezon-Master 400 (Switzerland)".

Mathematical processing of the study results was carried out using the statistical software package "EXCEL" and "STATISTICA".
Gums mucous membrane biopsies of patients-smokers were the material of pathomorphological study. The material was fixed in a $10 \%$ solution of neutral formalin for 24-48 hours, dehydrated in alcohols, and then poured into paraffin blocks. Slices from the paraffin blocks (5-6 $\mu \mathrm{m}$ of thickness) were made using a MPS-2 sledge microtom.

General histomorphology was studied on drugs stained with hematoxilin-eosin and by the method of Gerlich and van Gieson. Elastic fibers were detected by Weigert's resorcinol-fuchsin, argyrophilic, or reticulinimpregnation were detected with the help of Foot's silver nitrate. The intensity of histochemical reactions in all studied cases was evaluated visually using a semiquantitative evaluation method. Descriptive method of analysis of the revealed changes was used.

The preparations were examined using a microscope "LOMO Mikmed-2" and "Leica DFE420" at magnification $\times 100, \times 400, \times 900$ and documented.

Gum preparations were photographed using a microscope MS-300 with a camera and adapter, with software Micromed Images, followed by analysis.

The research was conducted at the Department of Pathological Anatomy and Forensic Medicine of Danylo Halytsky Lviv National Medical University.

Index characteristics of periodontal tissues of patients with IPD (smokers and non-smokers) with chronic toxic hepatitis $(\mathrm{M} \pm \mathrm{m})$

\begin{tabular}{|c|c|c|c|}
\hline Groups Indicators & $\begin{array}{c}\text { Comparison group } \\
(\mathbf{n}=\mathbf{2 2})\end{array}$ & $\begin{array}{c}\text { Group I } \\
(\mathbf{n}=\mathbf{2 6})\end{array}$ & $\begin{array}{c}\text { Group II } \\
(\mathbf{n}=\mathbf{3 8})\end{array}$ \\
\hline SN, points & $1,72 \pm 0,02$ & $2,09 \pm 0,11^{*}$ & $2,17 \pm 0,02^{* \#}$ \\
\hline S-L, points & $1,21 \pm 0,02$ & $2,11 \pm 0,21$ & $2,43 \pm 0,02$ \\
\hline PMA, \% & $38,32 \pm 0,61$ & $49,50 \pm 0,79^{*}$ & $58,73 \pm 0,38^{* \#}$ \\
\hline PBI, points & $0,90 \pm 0,07$ & $1,31 \pm 0,04^{*}$ & $1,53 \pm 0,04^{* \#}$ \\
\hline
\end{tabular}

Note: ${ }^{*}$ - confidence factor $(\mathrm{p}<0.05)$ compared to the comparison group.;

\# - confidence index $(\mathrm{p}<0.05)$ between groups I and II

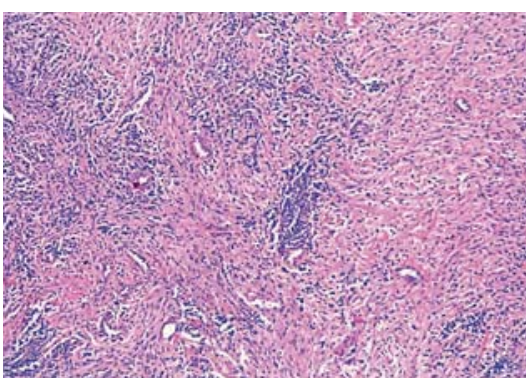

Pict. 1. Swelling of the microvascular blood flow vessels endothelium. Perivascular lymphohistiocytic infiltration $\times \mathbf{1 0 0}$.

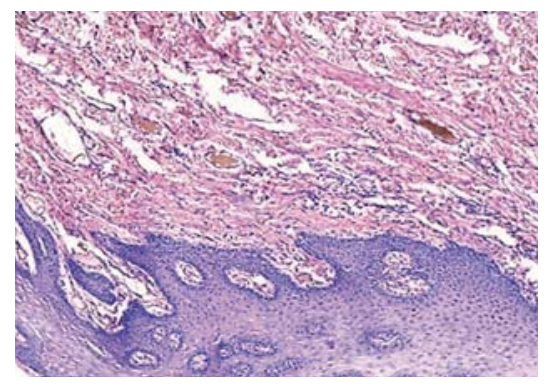

Pict. 2. Hyperemia and arterioles microthrombuses; interstitial stromal edema $\times 100$

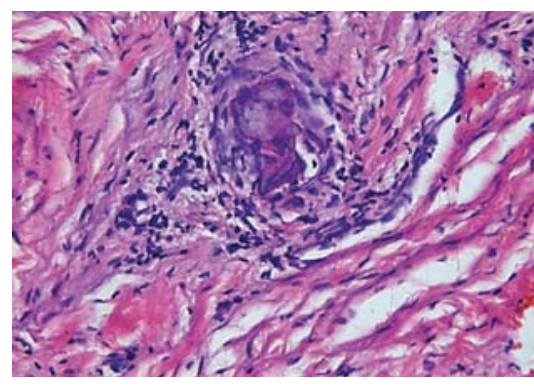

Pict. 3. Vessels arteriosclerosis (calcification) of muscular-elastic type of lamina propria of the mucosa with a significant stenosis of the lumen $\times \mathbf{9 0 0}$. 


\section{Results}

Table 1 presents the results of determining the clinical parameters of the oral cavity of patients under study.

It is established that the indicator of SN had the highest value among patients of group II $(2,15 \pm 0,13)$, it was probably $(\mathrm{p}<0.05)$ higher relatively to the group I and comparison group. Results of hygienic index S-L showed that the highest value was also in the II -nd group of patients, which is significantly $(\mathrm{p}<0.05)$ higher than that in the I-st group of patients and in the comparison group. Similar data can be observed while analyzing the indicators of the index of bleeding - the highest rate is $1.53 \pm 0.04$ in group II of patients, and the lowest $(0.90 \pm 0.07)$ - in patients of the comparison group without somatic pathology and without bad habits, where $\mathrm{p}<0.05$.

Dystrophic and inflammatory changes were observed among the smoking patients with chronic toxic hepatitis, which affected all the structural elements of the periodontium. In separate layers of the epithelium the damage processes were predominant, in particular: spinous layer -karyorhexis, karyolysis with the formation of cell debris; basal layer cell proliferation, acanthosis, angiogenesis.

In microvascular blood flow vessels there were swelling and homogenizate endothelium, focal fibrinoid necrosis, hyalinosis of arterioles (Pict. 1).

Activation of the inflammatory process was accompanied by the phenomena of hyperemia, exudation, interstitial edema, microthrombosis of arterioles (Pict. 2).

With the help of histochemical techniques, we were able to detect damage to collagen and elastic fibers of the periodontal. The severity of the collagen skeleton disor- ganization correlated with the intensity and duration of the bad habit. Swelling and hemogenic bundles of collagen fibers, fibrinoid necrosis, sclerosis, hyalinosis were found. In areas of pronounced alterative changes (degeneration, necrosis) colonies of bacteria were discovered (Pict. 3.).

The activity of the reaction to glycogen indicated the dependence of the glycogen content on the degree of damage to the periodontium and the intensity of regenerative changes. The most active glycogen depots were the surface and middle layers of epithelial cells.

Redistribution of acidic and neutral mucopolysaccharides in the mucosal lamina propria indicates the depth and degree of restructuring of the periodontal connective tissue, which leads to a decrease in its function.

\section{Conclusions}

With the help of clinical and histological studies, we have seen that the likelihood of inflammatory periodontal disease of patients with chronic toxic hepatitis who are smokers increases. And also, the severity of inflammatory diseases depends on the activity of this pathology and the presence of a bad habit, which is Smoking.

Thus, the results obtained in nicotine-dependent patients with chronic toxic hepatitis visualize a distinct damaging effect on the epithelium of the oral cavity, which leads to accelerated death and cells atrophy of its surface layer. This, in turn, leads to functional restructuring, weakening of the histohematic barrier of the oral cavity and promotes optimal conditions for the reproduction of pathogenic microflora and its penetration into the underlying tissues. Changes in the microvascular flow are associated with a systemic decrease in oxygenation and an increase in free radical oxidation.

\section{REFERENCES}

1. Levitskyi AP, Demyanenko SA. Hepato-oral syndrome. Simferopol: PE Tarpan, Publishing House. 2012; 140. [In Ukrainian].

2. Levitskyi AP, Demyanenko SA, Tsiselsky YuV. The antimicrobial function of the liver. Odessa: KP OGT 2011. 141. [In Ukrainian].

3. Borys HZ, Selivans'ka IO, Levyts'kyy AP. Vplyv antydysbiotychnykh zasobiv na biokhimichni pokaznyky slynnykh zaloz shchuriv za umov nealkohol'noho steatohepatytu. Odes'kyy medychnyy zhurnal. 2016; 3: 5-9. [In Ukrainian].

4. Abrahamovych MO, Ferko MR. Kharakterystyka syntropichnykh komorbidnykh pozapechinkovykh urazhen' u khvorykh na tsyroz pechinky zalezhno vid stupenya vazhkosti portal'noyi hipertenziyi. L'vivs'kyy klinichnyy visnyk. 2016; 2(14)-3 (15) : 30-40. [In Ukrainian].

5. Furdychko Al, Hasiuk PA, Ivanchyshyn W, Hasiuk NV. Clinical-laboratory justificationof dependence of periodontal inflammatory diseases on the condinion of hepatobiliary system. World of Medicine and Biology. 2018; 1(63): 87-89. [In Ukrainian].

6. Grigoryan AS, Grudyanov Al, Antipova SP. Cytological indicators as criteria for assessing the state of periodontal // Dentistry. 2000; 3: 17- 21.

7. Zubachyk VM, Ilchyshyn MP. Shkidlyvist' vplyvu tyutyunopalinnya na stan tkanyn porozhnyny rota u pidlitkiv ta osib molodoho viku. Novyny stomatolohiyi. 2008; 3 (56): 48-51. [In Ukrainian].

8. Hodovana Ol. Suchasni osnovy etiolohiyi ta patohenezu heneralizovanoyi dystrofichno-zapal'noyi khvoroby parodontu z suputn'oyu systemnoyu osteopeniyeyu. Visnyk problem biologii ta mediciny. 2017; 1 (137): 36- 41. [In Ukrainian].

9. Effects of nicotine on gene expression and osseointegration in rats / S. Yamano, JA. Berley, WP. Kuo [et al.] // Clin. Oral Impl. Res. 2010; 21: 1353- 1359.

10. Influence of smoking on clinical parameters and gingival crevicular fluid volume in patients with chronic periodontitis / SA. Mokeem, S. Vellappally, RS. Preethanath, MI. Hashem, [et al.] // Oral Health Dent Manag. 2014; 13: 469- 473.

11. Babenja AA. Oral Hygiene of patients with Acute Generalized Periodontitis. Stomatol. 2012; 3: 116.

12. Ilchyshyn MP, Furdychko Al., Barylyak AYa. Poshyrenist zakhvoryuvan parodontu sered tyutyunozalezhnykh osib. Novyny stomatolohiyi. $2018 ; 4$ (97): 86-88. [(In Ukrainian]. 
Особливості розвитку запальних захворювань тканин пародонта у нікотинозалежних хворих на хронічний токсичний гепатит

\author{
А. Фурдичко, М. Ільчишин, А. Бариляк, І. Федун, Л. Хороз
}

Вступ. Захворювання печінки та патологія органів порожнини рота взаємопов'язані. Куріння, як правило, посилює прояви основного захворювання і впливає на перебіг.

Мета. Дослідити вплив хронічного токсичного гепатиту нікотинозалежних пацієнтів та пацієнтів без шкідливої звички на їх пародонтологічний статус

Матеріали і методи. Під час клінічного обстеження ротової порожнини у 86 пацієнтів, досліджували глибину та частоту запалення ясен за допомогою числа Свракова (ЧС); стан гігіени порожнини рота оцінювали за допомогою індексу Silness-Loe (S-I); Пародонтальний індекс (PMA) та індекс кровотечі (PBI). Загальну гістоморфологію вивчали на препаратах, забарвлених гематоксилін-еозином, та методом Герліха та Ван-Гісона.

Результати. Встановлено, що показник ЧС мав найвище значення серед паціентів II групи $(2,15 \pm 0,13$ балів), він, вірогідно, (p <0,05) був вищим порівняно з І групою та групою порівняння. У пацієнтів, що палять з хронічним токсичним гепатитом, у остистому шарі епітелію визначали детермінантний каріоргексис, каріолізис з утворенням клітинних уламків; проліферація клітин базального шару, акантоз, ангіогенез. Ми виявили пошкодження колагенових та еластичних волокон пародонта, що корелювало з інтенсивністю та тривалістю шкідливої звички. У ділянках виражених альтеративних змін були виявлені колонії бактерій. Висновки. Таким чином, результати, отримані у нікотинозалежних пацієнтів із хронічним токсичним гепатитом, візуалізують пошкоджуючу дію на епітелій і послаблення гістогенетичного бар'єру порожнини рота та сприяють розмноженню й проникненню патогенної мікрофлори в товщу тканини.

Ключові слова: пародонт, хронічний токсичний гепатит, нікотинозалежність.

Особенности развития воспалительных заболеваний тканей пародонта у никотинозависимых больных хроническим токсический гепатит

А. Фурдъчко, М. Ильчишин, А. Бариляк, И. Федун, Л. Хороз.

Введение. Заболевания печени и патология органов полости рта взаимосвязаны. Курение, как правило, усиливает проявления основного заболевания и влияет на его ход.

Цель. Исследовать влияние хронического токсического гепатита никотинозависимых пациентов и пациентов без вредной привычки на их пародонтологический статус

Материалы и методы. Во время клинического обследования ротовой полости в 86 пациентов, исследовали глубину и частоту воспаления десен с помощью числа Свракова (ЧС); состояние гигиены полости рта оценивали с помощью индекса Silness-Loe (S-I) Пародонтальный индекс (PMA) и индекс кровотечения (РВI). Общую гистоморфологию изучали на препаратах, окрашенных гематоксилин-эозином, и методом Герлиха и Ван Гисона.

Результаты. Установлено, что показатель ЧМ имел высокое значение среди пациентов II группы $(2,15 \pm 0,13$ баллов), он, вероятно, ( $<<0,05)$ был выше по сравнению c I группой и группой сравнения. В курящих пациентов с хроническим токсическим гепатитом, в остистому слое эпителия определяли детерминантный кариоргексис, кариолизис с образованием клеточных обломков; пролиферация клеток базального слоя, акантоз, ангиогенез. Мы обнаружили повреждения коллагеновых и эластичных волокон пародонта, что коррелировало с интенсивностью и продолжительностью вредной привычки. В участках выраженных альтернативных изменений были обнаружены колонии бактерий.

Выводы. Таким образом, результаты, полученные в никотинозависимых пациентов с хроническим токсическим гепатитом, визуализируют повреждающее действие на эпителий и ослабление гистогенетической барьера полости рта и способствуют размножению и проникновению патогенной микрофлоры в толщу ткани. Ключевые слова: пародонт, хронический токсический гепатит, никотинозалежнисть.

Furdychko Anastasya I. - PhD, Associate Professor of Department of Therapeutic Dentistry,

Danylo Halytskyy Lviv National Medical University, 3a/1, Peremyska St.

Tel.: +38067-688-02-14, e-mail: anfurd111@gmail.com.

Ilchyshyn Marta P. - PhD, Assistant of Department of Therapeutic Dentistry,

Danylo Halytskyy Lviv National Medical University. Tel.: +38097-585-49-48, e-mail: immartella@gmail.com.

Barylyak Adriana Ya. - PhD, Assosiate of Professor of Department of Therapeutic Dentistry,

Danylo Halytskyy Lviv National Medical University. Tel.: +38067-733-76-05, e-mail: adriana.barylyak5@gmail.com.

Fedun Irena R. - PhD, Assistant of Department of Therapeutic Dentistry,

Danylo Halytskyy Lviv National Medical University. Tel.: +38097-558-49-58, e-mail: irenafedun@gmail.com.

Khoroz Lesya M. - PhD, Associate Professor of Department of Therapeutic Dentistry,

Danylo Halytskyy Lviv National Medical University. Tel.: +38067-998-00-53, e-mail: khoroz.lesya@gmail.com.

The research was conducted at Danylo Halytsky Lviv National Medical University,

Department of therapeutic dentistry, head of the Department - prof. Zubachyk V.M. 